\title{
Benzene and toluene in the surface air of northern Eurasia from TROICA-12 campaign along the Trans-Siberian Railway
}

\author{
Andrey I. Skorokhod, Elena V. Berezina, Konstantin B. Moiseenko, Nikolay F. Elansky, and Igor B. Belikov \\ A.M. Obukhov Institute of Atmospheric Physics, Russian Academy of Sciences, Moscow, 119017, Russia \\ Correspondence to: Andrey I. Skorokhod (askorokhod@mail.ru) and Elena V. Berezina (e_berezina_83@mail.ru)
}

Received: 27 September 2016 - Discussion started: 28 October 2016

Revised: 29 March 2017 - Accepted: 4 April 2017 - Published: 2 May 2017

\begin{abstract}
Volatile organic compounds (VOCs) were measured by proton transfer reaction mass spectrometry (PTRMS) on a mobile laboratory in a transcontinental TROICA12 (21 July-4 August 2008) campaign along the TransSiberian Railway from Moscow to Vladivostok. Surface concentrations of benzene $\left(\mathrm{C}_{6} \mathrm{H}_{6}\right)$ and toluene $\left(\mathrm{C}_{7} \mathrm{H}_{8}\right)$ along with non-methane hydrocarbons (NMHCs), $\mathrm{CO}, \mathrm{O}_{3}, \mathrm{SO}_{2}$, $\mathrm{NO}, \mathrm{NO}_{2}$ and meteorology are analyzed in this study to identify the main sources of benzene and toluene along the TransSiberian Railway. The most measurements in the TROICA12 campaign were conducted under low-wind/stagnant conditions in moderately ( $\sim 78 \%$ of measurements) to weakly polluted ( $\sim 20 \%$ of measurements) air directly affected by regional anthropogenic sources adjacent to the railway. Only $2 \%$ of measurements were identified as characteristic of highly polluted urban atmosphere. Maximum values of benzene and toluene during the campaign reached 36.5 and $45.6 \mathrm{ppb}$, respectively, which is significantly less than their short-term exposure limits ( 94 and $159 \mathrm{ppb}$ for benzene and toluene, respectively). About $90 \%$ of benzene and $65 \%$ of toluene content is attributed to motor vehicle transport and 10 and $20 \%$, respectively, provided by the other local- and regional-scale sources. The highest average concentrations of benzene and toluene are measured in the industrial regions of the European Russia (up to 0.3 and $0.4 \mathrm{ppb}$ for benzene and toluene, respectively) and south Siberia (up to 0.2 and $0.4 \mathrm{ppb}$ for benzene and toluene, respectively). Total contribution of benzene and toluene to photochemical ozone production along the Trans-Siberian Railway is about $16 \%$ compared to the most abundant organic VOC - isoprene. This contribution, however, is found to be substantially higher (up to $60-70 \%$ ) in urbanized areas along the railway, suggest-
\end{abstract}

ing an important role of anthropogenic pollutant sources in regional ozone photochemistry and air quality.

\section{Introduction}

Aromatic compounds is an important class of hydrocarbons taking a significant part in the formation of tropospheric ozone and the secondary pollutants, including organic aerosols, that can lead to photochemical smog (Wayne, 2000; Baltaretu et al., 2009). Being toxic and carcinogenic, these gases, even without chemical transformation, have multiple impacts on the environment and human health (Derwent et al., 2000; Calvert et al., 2002; Lippmann, 2009). Thus, it is very important to study the role of aromatic compounds in air pollution for improving air quality.

A dominant source of aromatic compounds, particularly in urban environments, is automobile emissions with significant emissions being also from their use as solvents in various manufacturing processes (Wayne, 2000). Aromatic compounds can make up to $30-40 \%$ of the total non-methane hydrocarbon (NMHC) content in the atmosphere, and are responsible for about $40 \%$ of the ozone producing potential of all NMHCs (Derwent et al., 2000; Calvert et al., 2002; Mugica et al., 2003; North et al., 2015).

In anthropogenically loaded regions, the most abundant aromatic compounds usually include benzene and toluene, which we focused our effort on in this study. They are often associated with air emissions from petroleum production industries (motor vehicle exhaust, incomplete combustion of fossil fuels, oil and gas service stations, and other industrial and human activities). Filella and Peñuelas (2006), White 


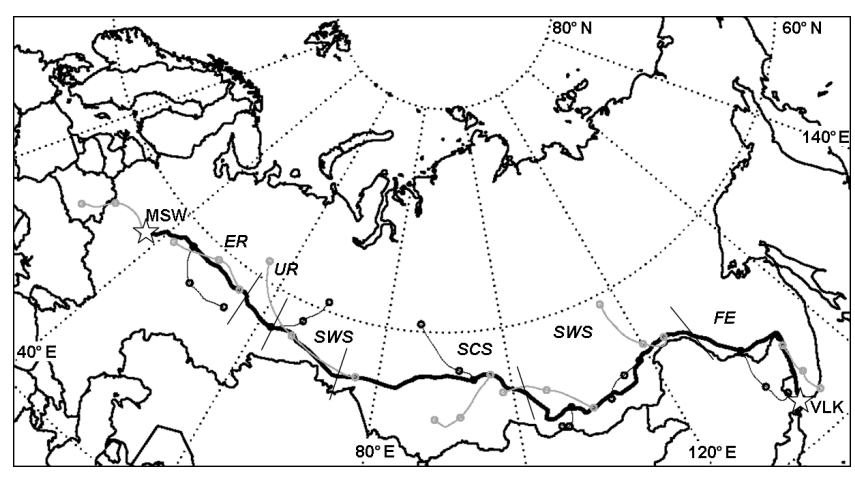

Figure 1. Schematic representation of the TROICA-12 route from Moscow (MSW) to Vladivostok (VLK). Thin solid lines across the route represent approximate boundaries of various geographic regions: European Russia (ER), Ural Mountains region (UR), southern parts of west (SWS), central (SCS), and east (SES) Siberia, and the Far East region (FE). Backward 2-day trajectories with endpoints at Trans-Siberian Railway at local noon of each successive day of carriage movement are shown for east (black solid) and west (gray solid) routes of the campaign. Open circles mark air particle positions at 0,24 , and $48 \mathrm{~h}$ along the each trajectory.

et al. (2009) and Parra et al. (2006) also point to biogenic sources of benzene and toluene in summer rural conditions.

Many studies on benzene and toluene in urban and rural atmosphere have been carried out around the world (e.g., Keymeulen et al., 2001; Barletta et al., 2005; Parra et al., 2006; Velasko et al., 2007; Tivary et al., 2010; Miller et al., 2011; Civan et al., 2011; Chaudhary et al., 2012; Shaw et al., 2015). However, there is still a substantial lack of information on benzene and toluene abundance and spatial localization in remote areas of the North Eurasia, although some studies were performed by Elansky at al. (2001) and Timkovsky et al. (2010). This gap is partially filled from the TROICA-12 campaign on a mobile carriage laboratory in summer 2008, during which complex measurements of surface air chemical composition were conducted along the Trans-Siberian Railway from Moscow to Vladivostok $(\sim 9300 \mathrm{~km})$.

This study aims to investigate variation in benzene and toluene in the surface air over Russia from PTR-MS measurements to determine their characteristic levels in urban, rural, and remote atmosphere in different geographic regions with respect to their major regional sources including large towns and industrial areas along the railway. The relative importance of benzene and toluene emissions in photochemical near-surface ozone production is then assessed with respect to a major biogenic ozone precursor, isoprene (Chameides et al., 1992; Geng et al., 2011).

\section{Methods}

\subsection{TROICA experiments}

TROICA experiments over Russia on a mobile laboratory have been carried out regularly since 1995 (Elansky et al., 2009). About 10 inorganic compounds (ozone, nitric oxides, carbon oxides, methane, sulfur dioxide etc.) as well as aerosols and meteorological parameters (air temperature, pressure and humidity, solar radiation, vertical temperature profiles, wind speed and direction; at stops) were measured continuously and simultaneously by a specially constructed automated system. The system was built on a railway carriage with air inlets at the height of about $4 \mathrm{~m}$ above the ground. VOC concentrations have been measured routinely since 2008 (TROICA-12, -13 and -14 campaigns). The TROICA carriage laboratory is equipped in accordance with the measurement requirements of the Global Atmospheric Watch (WMO), and is located just after the electric locomotive to minimize various effects of near-surface air perturbations due to moving train. The possible impact of oncoming trains, e.g., those transporting oil products as well as human activities in the train (all conveniences were placed at the end part of the train) on the measurements, has been removed through the respective time filtering of the original data. We also note that this impact is expected to be generally non-significant as demonstrated previously in Crutzen et al. (1998), Elansky et al. (2000) and Panin et al. (2001).

In present study, the data from the summer experiment TROICA-12 (21 July-4 August 2008) along the TransSiberian Railway (Fig. 1) are analyzed. The train covers the total length of the route from Moscow to Vladivostok ( $\sim 9288 \mathrm{~km}$ ) for approximately 6 days, so the total duration of a single campaign is about 2 weeks. (Henceforth, we denote the forward path from Moscow to Vladivostok and the return path from Vladivostok to Moscow as east and west segments of the whole route, respectively.)

Undoubtedly, the results of the observations at each particular location performed from the moving carriage are strongly influenced by specific weather conditions (synoptic patterns), as well as by complex interplay of local pollution sources and atmospheric transport by turbulent eddies on a variety of scales, the latter being considered as a source of random noise in the measurement data. Generally, straightforward quantification of the effects of atmospheric dilution and absolute strength of the associated nearby emission sources is inhibited in data analyses. Yet, the passage of each location twice (in the forward and return paths of the TROICA campaign) allows for some qualitative assessment of the impact of weather conditions, since the time between the two subsequent measurements is of the order of 1 week, which is comparable to the characteristic time of boundary layer ventilation in mid-latitudes.

Various types of meteorological conditions along the railway can be generalized into three distinctive weather pat- 
terns when traversing mountain area adjacent to Lake Baikal $\left(\sim 110^{\circ} \mathrm{E}\right)$ in east and west segments. There was clear and warm $\left(>20^{\circ} \mathrm{C}\right.$ at noon) weather on the route from Moscow to Lake Baikal, hot weather $\left(>24^{\circ} \mathrm{C}\right.$ at noon) between Lake Baikal area and Vladivostok (east and west segments), and cool (daytime temperatures of $15-20^{\circ} \mathrm{C}$ ) and rainy weather between Lake Baikal and Moscow on the return west segment of the route. Nighttime surface temperature inversions and stagnant air conditions were common for the east segment, although light winds were typical for both the east and west segments of TROICA. This feature is clearly seen in Fig. 1, where 2-day back trajectories along the TROICA route calculated with the use of NOAA HYSPLIT model (Stein et al., 2015) based on 3-D wind fields are shown as averages of corresponding ensembles of trajectories originated within a height range from 0 to $400 \mathrm{~m}$ a.g.1. According to Fig. 1, the characteristic distances of transport within a planetary boundary layer do not exceed $500-600 \mathrm{~km}$ in the 2 days preceding measurement time, so the measured chemical composition of the respective air masses can be considered as representative of the cumulative impact of pollutant sources at local to regional scales. Relatively low wind speeds and short chemical lifetimes of the analyzed species ( $\sim 12$ days for benzene and $\sim 2-4$ days for toluene) support a regional approach to data analyzes implemented in present study (see Sect. 3) to quantify impact of various anthropogenic sources (large towns and industrial facilities) localized primarily along the railway. The exception is the Far East region, where regional advection by southerly winds may contribute to measured pollutant concentrations from highly urbanized areas of the northeast China.

\subsection{VOC measurements}

VOC concentrations were measured by a compact proton transfer reaction mass spectrometer (compact PTR-MS) from Ionicon Analytik GmbH, Austria. One of the advantages of the compact PTR-MS is portability, which allows its use for continuous measurements on a mobile moving platform. Another large advantage of the compact PTR-MS is that the volatile compound samples do not need to be specially prepared before the measurement, e.g., involving preconcentration procedures; thus, headspace samples can be introduced directly into the reaction chamber consisting of the drift tube. The fact that, due to their low proton affinities, $\mathrm{H}_{3} \mathrm{O}^{+}$ions do not react with any of the major components present in clean air is an additional advantage as it allows the analyzed air to be used directly as the buffer gas. To set a correct transmission in the software, a gas standard (Ionicon Analytik GmbH, Innsbruck) containing 17 VOCs including benzene, toluene and isoprene was used. Error in calibration by the gas standard did not exceed $15 \%$. The instrument allows the simultaneous online monitoring of $20 \mathrm{VOCs}$, including benzene, toluene, xylene, propylbenzene, isoprene, monoterpenes and others.
The compact PTR-MS consists of three main components: an ion source, a drift tube, and a mass analyzer (quadrupole mass spectrometer) in conjunction with an ion detector/amplifier. $\mathrm{H}_{3} \mathrm{O}^{+}$ions are produced in high concentrations from pure water vapor within a hollow cathode discharge ion source. These primary ions pass into the drift tube, where they undergo (mostly) non-dissociative proton transfer to the VOCs that are to be detected. The air sample to be analyzed is introduced into the drift tube (which is maintained at about 2 mbar and $40{ }^{\circ} \mathrm{C}$ with a drift voltage of $600 \mathrm{~V}$ ) close to its entrance at a typical flow rate of about $11 \mathrm{~mL} \mathrm{~min}^{-1}$.

The compact PTR-MS measurement range depends on the substances measured, integration time and system setup. Its detection limits for the investigated VOCs are of the order of pptv. The ions associated with benzene and toluene are free from significant interferences of other VOC species (Warneke et al., 2003). In the case of isoprene, other aldehydes and ketones are known to be detectable at this mass (Warneke et al., 2003; Fortner et al., 2009). However, isoprene has been found to be the dominant species at mass 69 within various kinds of air masses (de Gouw and Warneke, 2007). Nevertheless, the isoprene signal should be interpreted carefully, particularly from coniferous forests, where emissions of 2-methyl-3-buten-2-ol, which is also determined at mass 69 , take place.

\subsection{Other components and meteorology}

Concentrations of non-methane hydrocarbons (NMHCs) were measured with an APHA-360 instrument (Horiba, Japan). This gas analyzer separates $\mathrm{CH}_{4}$ and NMHC by using selective catalytic absorbers and measures the gas concentrations with a flame ionization detector. The total error in the $\mathrm{CH}_{4}$ and NMHC concentration measurements does not exceed $\pm 5 \mathrm{ppb}$. To supply the flame ionization detector with hydrogen, which is necessary for its operation, the instrumentation set has hydrogen generators of different types. To make proper measurement accuracy, the zero calibration for every $20 \mathrm{~min}$ of the measurements and daily span calibrations were carried out in the campaign. The calibrations were performed using the gas standards provided by the D.I. Mendeleev All-Russian Institute for Metrology.

CO concentration was measured with a TE48S instrument (Thermo Electron Corp.). This instrument uses an advanced method based on the measurements with the correlation of gas filters. It allows for measuring background CO concentrations at a level of less than $100 \mathrm{ppb}$ with the total error of $\pm 10 \mathrm{ppb}$.

$\mathrm{SO}_{2}$ concentration was measured with an APSA-360 instrument (Horiba, Japan). This instrument measures $\mathrm{SO}_{2}$ chemiluminescence induced by UV radiation. For scheduled calibrations zero-air generator is used.

$\mathrm{NO}$ and $\mathrm{NO}_{2}$ concentrations were measured at different times with a TE42C-TL instrument (Thermo Electron Corp., USA) and with a M200AU instrument produced by Tele- 


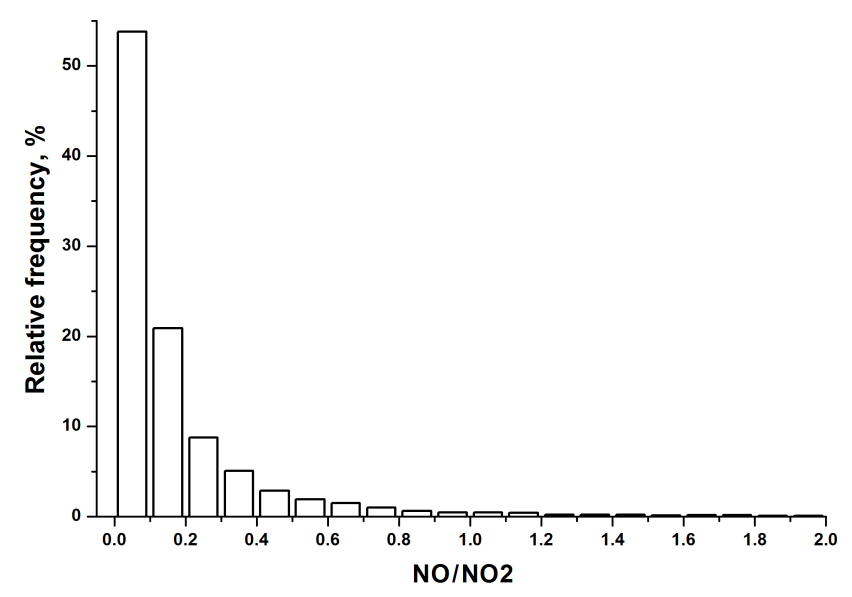

Figure 2. Relative frequency of $\mathrm{NO} / \mathrm{NO}_{2}$ values in the TROICA12 campaign.

dyne Corp. (USA). These instruments apply the chemiluminescence method. The minimum $\mathrm{NO}$ and $\mathrm{NO}_{2}$ concentrations detectable with these instruments are equal to $0.05 \mathrm{ppb}$, which makes it possible to measure the so-called background concentrations not influenced by the pollution sources. $\mathrm{NO}_{x}$ concentration is the sum of $\mathrm{NO}$ and $\mathrm{NO}_{2}$ concentrations.

Ozone concentration was measured with Dasibi 1008RS and 1008AH gas analyzers. These instruments are based on the photometric method. They allow measuring the ozone concentration in the range from 1 to $1000 \mathrm{ppb}$ with a total error of $\pm 1 \mathrm{ppbv}$. These instruments undergo scheduled calibrations against the secondary standard, the O3-41M no. 1294 instrument, which undergoes in turn annual calibrations against the SRP no. 38 standard owned by the Mendeleev Research Metrology Institute (Russia).

For monitoring of meteorological parameters, the instrumentation set was constructed including the following instruments: an ACAT-3M acoustic anemometer (Russia), HMP233 transmitter and PTA427 barometric pressure transducer (Vaisala, Finland), and CM6B pyranometer (Driesen $\&$ Kem, Germany). The temperature profile up to a height of $600 \mathrm{~m}$ was measured with MTP-5 meteorological temperature profiler (ATTEX, Russia).

\subsection{Data processing}

The major problem in the TROICA data analyses is the correct elimination of screening effects (relative to regionalscale pollution sources) produced by local pollution sources along the railway. Except for small areas of biomass burning and smoldering in the vicinity of the railway, such sources are mainly of anthropogenic origin and characterized by highly limited spatial extents (and, hence, an impact upon a chemical composition), so they can be effectively filtered out by applying some objective criteria to the original $10 \mathrm{~s}$ dataset. Commonly, the chemical impact is characterized by strong short-time variations in $\mathrm{CO}, \mathrm{O}_{3}$, and $\mathrm{NO}_{x}$ concentrations and by an increase in the $\mathrm{NO} / \mathrm{NO}_{2}$ ratio well above its regional characteristic value of $\sim 0.1$. Upon a set of trials, we found that eliminating data points satisfying the criteria $\mathrm{NO} / \mathrm{NO}_{2}>0.2$ was sufficient to obtain robust statistics on measurement data concerning the regional effects of anthropogenic pollution. According to Fig. 2, such an approach results in eliminating $\sim 25 \%$ of data from the subsequent analyses, with the remaining data (which we hereafter refer to as the "filtered dataset") being safely attributed to the local- to regional-scale effects produced by sustained anthropogenic sources.

Statistical and graphical data analysis was performed with the free software environment for statistical computing and graphics, R (http://www.r-project.org/), and with the data analysis and graphing software OriginPro (OriginLab Corporation).

A statistical summary of the filtered dataset is shown in Table 1. In the east segment, toluene and benzene concentrations and their variations are somewhat higher compared to those for the west segment. As discussed above, this feature is most probably attributed to the observed differences in meteorological conditions, as the regional anthropogenic emission sources are not expected to vary at any appreciable rate on a sub-seasonal scale. Although atmospheric dilution rates and advection paths (see Fig. 1) vary significantly between the east and west segments, spatial localization of high levels of toluene and benzene near their emission sources (mostly large towns and their suburbs) strongly restricts the impact of meteorology on their near-surface abundance, at least at the regional scale, due to their relatively short chemical lifetime. Consequently, the observed systematic differences in toluene and benzene statistics between east and west segments were relatively small for both mean and percentile values.

\section{Results and discussion}

\subsection{Spatial distribution of benzene and toluene along the Trans-Siberian Railway}

The areas adjacent to the Trans-Siberian Railway are markedly different in the amount of urbanization and anthropogenic load. Eighty-seven towns are located immediately on the railway, 68 towns are in the Ural Mountains region and west Siberia, with the remaining ones located in east Siberia and the Far East region. Yet, it is in the area of the first tens to hundreds of kilometers from the Trans-Siberian Railway, where the most significant regional anthropogenic sources are commonly located in all the regions considered. Figure 3 shows 10 min averages of the surface concentrations of benzene and toluene derived from the filtered $10 \mathrm{~s}$ dataset for the east and west segments of the TROICA- 12 route. Simultaneous measurements of surface $\mathrm{NMHCs}, \mathrm{CO}$, and $\mathrm{SO}_{2}$ concentrations are also shown in the figure. 


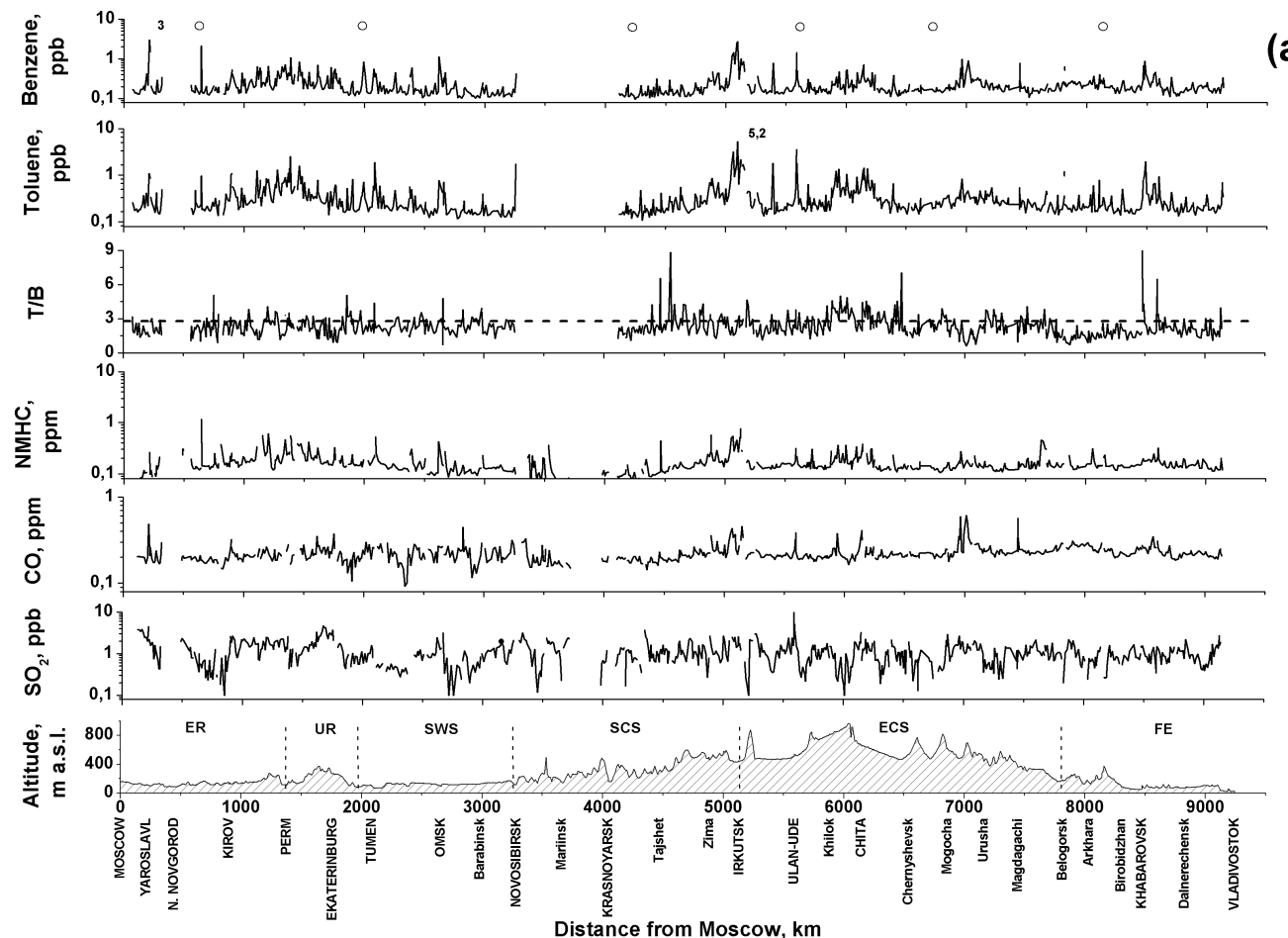

(a)

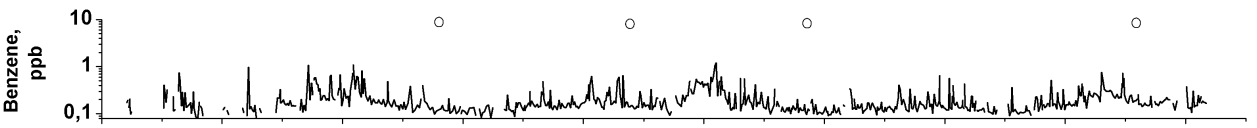

(b)

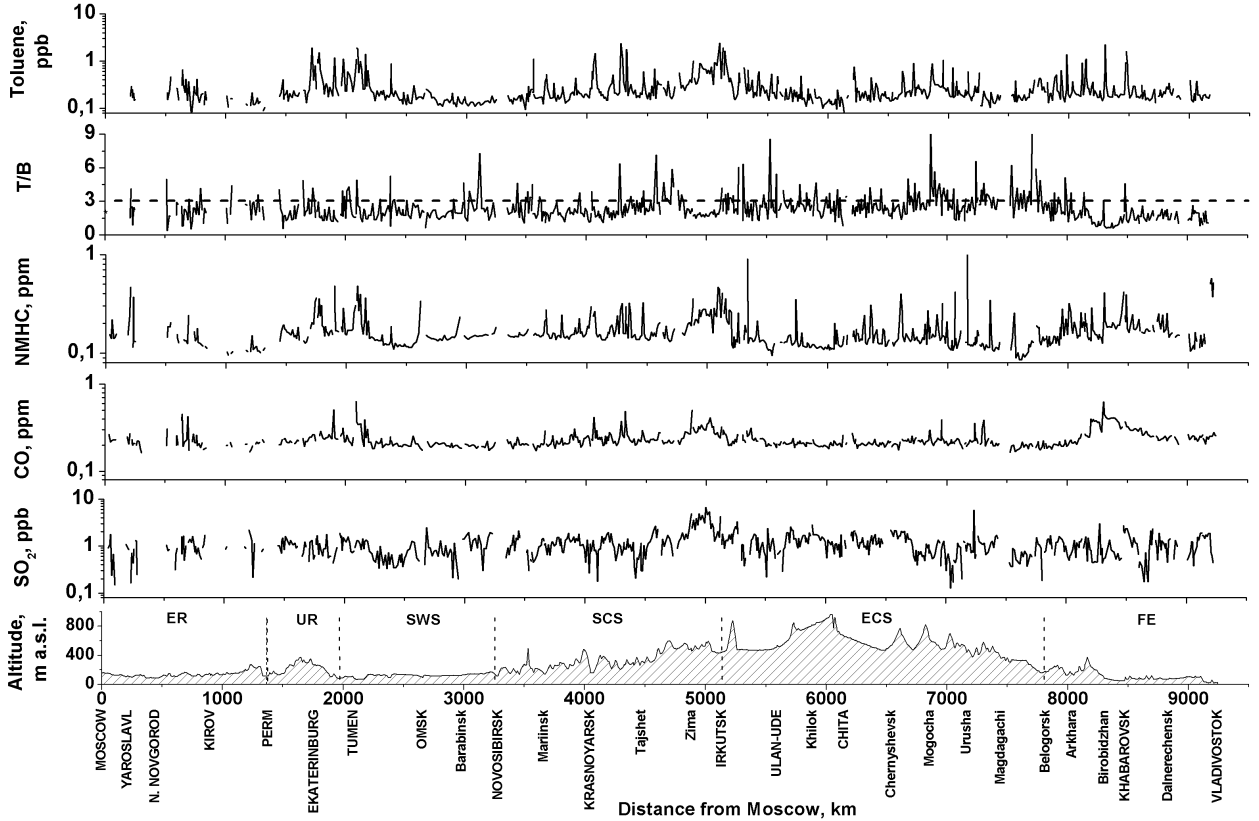

Figure 3. (a) 10 min concentrations of benzene, toluene, and $\mathrm{T} / \mathrm{B}$ ratio as well as NMHC, $\mathrm{CO}$ and $\mathrm{SO}_{2}$ along the Trans-Siberian Railway in the east segment of the TROICA-12 campaign. Some parameters are plotted in a logarithmic scale for better data presentation. White circles on the top of the figure indicate the times of local noon. The cities with a population from 250000 to 1 million or more are shown in capital letters. A dashed line shows the T / B boundary between transport and industrial emissions (Tiwary et al., 2010; Carballo-Pat et al., 2014). (b) Same as (a) but for the west segment of the TROICA-12 campaign. 
Table 1. Statistics for the filtered original $10 \mathrm{~s}$ data of benzene and toluene (in ppb) from the TROICA-12 campaign (E - east segment; W west segment). $N$ - total number of the original 10 s filtered samples; $\sigma$ - standard deviation; $P$ - percentiles.

\begin{tabular}{lcccccccc}
\hline TROICA segment & $N$ & Mean & $\sigma$ & Min & Max & $P_{10}$ & $P_{50}$ & $P_{90}$ \\
\hline \multicolumn{7}{c}{ Benzene } \\
\hline $\mathrm{E}$ & 39873 & 0.23 & 0.60 & 0.01 & 36.51 & 0.05 & 0.15 & 0.40 \\
$\mathrm{~W}$ & 36322 & 0.18 & 0.27 & 0.01 & 14.32 & 0.05 & 0.13 & 0.35 \\
\hline \multicolumn{7}{c}{ Toluene } \\
\hline $\mathrm{E}$ & 39873 & 0.34 & 0.79 & 0.01 & 45.58 & 0.07 & 0.21 & 0.62 \\
$\mathrm{~W}$ & 36322 & 0.27 & 0.48 & 0.01 & 25.89 & 0.06 & 0.17 & 0.50 \\
\hline
\end{tabular}

The observed simultaneous peaks in the concentrations of VOCs and inorganic compounds shown in the figure are spatially connected to the most significant regional anthropogenic sources along the railway (mostly in urban environments), which are mainly expected to be motor vehicle transport, industry, central heating, and power plants.

Although an exact quantitative input of various types of toluene and benzene sources into the observed concentrations remains unknown, some qualitative assessment of their relative importance can be done from a ratio of toluene to benzene ( $\mathrm{T} / \mathrm{B}$ ). The $\mathrm{T} / \mathrm{B}$ ratio is frequently used as an indicator of motor transport emissions, since toluene content in gasoline and automobile exhausts is in 3-4 times higher than the benzene content (D. Brocco et al., 1997). Therefore, $\mathrm{T} / \mathrm{B} \approx 1-3$ is widely accepted to indicate motor vehicle transport, whereas $\mathrm{T} / \mathrm{B}>3$ points to industrial exhausts (Tiwari et al., 2010; Shaw et al., 2014; Carballo-Pat et al., 2014). Furthermore, the chemical activity of toluene in the atmosphere is approximately 5 times higher than that of benzene. Hence, the T / B ratio can serve as an indicator of chemical aging and, consequently, proximity of the sampled air to the associated pollution source (Mugica et al., 2003; Tiwari et al., 2010; Carballo-Pat et al., 2014; Shaw et al., 2014).

Following our previous study on greenhouse gas emissions (Berezina et al., 2014), in the present analysis, we divide the whole path from Moscow to Vladivostok into six lengthy segments according to climatological conditions and anthropogenic load intensity: European Russia (ER), the Ural Mountains region (UR), southern parts of west (SWS), central (SCS), and east (SES) Siberia, and the Far East region (FE; see Fig. 1). Statistics for benzene, toluene, and $\mathrm{T} / \mathrm{B}$ from $10 \mathrm{~s}$ filtered data for different regions are shown in Table 2. The highest concentrations of benzene and toluene were observed in ER, UR, and SCS, which are the regions of most significant anthropogenic emission sources and proximity of the TROICA route to the strong pollution sources. Since the low/high T / B ratio measured at a given location can be equally attributed (in the absence of prior information) either to a photochemically aged/young air mass or specific chemical composition of the primary pollutants affected the measured air mass, we must distinguish between both fac- tors to use the T / $\mathrm{B}$ ratio as characteristic of the associated emission source. The problem is further complicated by the fact that the measured air represents commonly a mixture of air parcels with different photochemical age and/or anthropogenic loading. One partial solution consists in separating air masses according to their chemical aging (transport times from the regional pollution sources) based on some additional data on their chemical composition and/or transport times.

In the present work we utilized the former approach by invoking contemporary measurements of $\mathrm{NO}$ and $\mathrm{NO}_{2}$ to distinguish between clean remote air $\left(\mathrm{NO}_{x}<2 \mathrm{ppb}\right)$, moderately polluted air $\left(2 \leq \mathrm{NO}_{x}<20 \mathrm{ppb}\right)$ and highly polluted air $\left(\mathrm{NO}_{x} \geq 20 \mathrm{ppb}\right)$, the latter being representative of urban and suburban environments. Here, the exact threshold values of $\mathrm{NO}_{x}$ were chosen based on our experience in processing multiple datasets from TROICA campaigns as well as continuous measurements of $\mathrm{NO}_{x}$ at ZOTTO Tall Tower, a remote site in Central Siberia, which is occasionally affected by transport of polluted air from major regional anthropogenic sources in south Siberia (Vasileva et al., 2011). The statistical analysis of the filtered dataset showed that about $80 \%$ of the data account for moderately polluted air, $18 \%$ for clean remote air and only about $2 \%$ for highly polluted air. Thus, the measurements in the TROICA-12 campaign were performed mostly in a moderately polluted urban atmosphere $\left(2 \leq \mathrm{NO}_{x}<20 \mathrm{ppb}\right)$, with maximum concentrations of toluene and benzene reaching values of 45.6 and $36.5 \mathrm{ppb}$, respectively, which is significantly less than the short-term exposure limits (94 and 159 ppb for benzene and toluene, respectively).

Since high ( $\geq 2 \mathrm{ppb}$ ) $\mathrm{NO}_{x}$ are found to be a robust characteristic of photochemically young air (Vasileva et al., $2011)$, we use associated $\mathrm{T} / \mathrm{B}\left(\mathrm{NO}_{x}>2 \mathrm{ppb}\right)$ values to infer some qualitative information on the pollution sources characteristic for the given region. According to Table 3, average and median values of $\mathrm{T} / \mathrm{B}\left(\mathrm{NO}_{x}>2 \mathrm{ppb}\right)$ were in the ranges of $1.8-2.6$ and 1.1-1.6, respectively, which is well below the commonly accepted threshold value for the motor vehicle exhausts $(\mathrm{T} / \mathrm{B}<3)$. Yet, significantly higher $\mathrm{T} / \mathrm{B}$ ratios (the column $P_{90}$ of the table) were found in all 
Table 2. The regional statistics of benzene, toluene (in ppb) and T / B along the Trans-Siberian Railway: ER - European Russia; UR - Ural Mountains region; SWS - southern parts of west Siberia; SCS - southern parts of central Siberia; SES - southern parts of east Siberia; FE Far East region.

\begin{tabular}{lrrrrrrrr}
\hline Region & $N$ & Mean & $\sigma$ & Min & Max & $P_{10}$ & $P_{50}$ & $P_{90}$ \\
\hline \multicolumn{7}{c}{ Benzene } \\
\hline ER & 7456 & 0.28 & 1.10 & 0.01 & 36.51 & 0.08 & 0.16 & 0.43 \\
UR & 5464 & 0.28 & 0.42 & 0.01 & 12.22 & 0.08 & 0.20 & 0.49 \\
SWS & 10714 & 0.22 & 0.44 & 0.01 & 22.28 & 0.07 & 0.14 & 0.37 \\
SCS & 13120 & 0.25 & 0.64 & 0.01 & 35.35 & 0.07 & 0.16 & 0.45 \\
SES & 26228 & 0.20 & 0.26 & 0.01 & 14.99 & 0.07 & 0.15 & 0.36 \\
FE & 13212 & 0.22 & 0.28 & 0.01 & 15.81 & 0.08 & 0.17 & 0.38 \\
\hline & & \multicolumn{7}{c}{ Toluene } \\
ER & 7456 & 0.35 & 0.65 & 0.01 & 32.10 & 0.09 & 0.23 & 0.67 \\
UR & 5464 & 0.39 & 0.86 & 0.01 & 32.82 & 0.10 & 0.27 & 0.70 \\
SWS & 10714 & 0.28 & 0.56 & 0.01 & 17.26 & 0.07 & 0.17 & 0.48 \\
SCS & 13120 & 0.37 & 0.89 & 0.01 & 38.58 & 0.08 & 0.21 & 0.71 \\
SES & 26228 & 0.31 & 0.59 & 0.01 & 45.58 & 0.09 & 0.21 & 0.55 \\
FE & 13212 & 0.28 & 0.63 & 0.01 & 40.67 & 0.08 & 0.18 & 0.45 \\
\hline
\end{tabular}

Table 3. $\mathrm{T} / \mathrm{B}$ ratio for moderately to strongly polluted air $\left(\mathrm{NO}_{x}>2 \mathrm{ppb}\right)$.

\begin{tabular}{lrrrrrrrr}
\hline Region & $N$ & Mean & $\sigma$ & Min & Max & $P_{10}$ & $P_{50}$ & $P_{90}$ \\
\hline ER & 4247 & 2.20 & 2.63 & 0.04 & 41.71 & 0.49 & 1.53 & 4.26 \\
UR & 3801 & 2.26 & 2.90 & 0.04 & 49.00 & 0.52 & 1.51 & 4.40 \\
SWS & 6685 & 2.27 & 3.28 & 0.01 & 57.65 & 0.40 & 1.37 & 4.63 \\
SCS & 10732 & 2.28 & 3.08 & 0.02 & 72.13 & 0.48 & 1.50 & 4.44 \\
SES & 21824 & 2.58 & 3.73 & 0.03 & 187.77 & 0.49 & 1.61 & 5.30 \\
FE & 11645 & 1.84 & 3.01 & 0.01 & 87.86 & 0.33 & 1.10 & 3.62 \\
\hline
\end{tabular}

the regions, suggesting other important regional sources of air contamination. These high values were measured commonly as short-lasting events where the mobile laboratory crossed the plumes of strongly contaminated air originating from large upwind emission sources, as evidenced from air trajectory analyses and prior data on industrial facilities. In such cases, high toluene and benzene concentrations are accompanied with enhanced levels of $\mathrm{NMHC}, \mathrm{CO}$, and $\mathrm{SO}_{2}$ as well, indicating the petrochemical and refining exhausts. These include heat and power plants in the vicinities of large towns: Perm, Tyumen, Omsk, Ulan-Ude, Chita, Khabarovsk (Fig. 3a), Yekaterinburg, Tyumen, Krasnoyarsk, Kansk, Irkutsk, Mogocha, Birobidzhan, and Khabarovsk (Fig. 3b).
Table 4. The bulk contribution of motor vehicle exhausts, $\chi(\%)$ to the near-surface abundance of $\mathrm{T}$ and $\mathrm{B}$ along the Trans-Siberian Railway (see Eq. 1).

\begin{tabular}{lrrrrr}
\hline TROICA segment & $\bar{T}_{\text {low }}$ & $t_{\text {low }}$ & $\bar{T}_{\text {high }}$ & $t_{\text {high }}$ & $\chi(\%)$ \\
\hline \multicolumn{7}{c}{ Benzene } \\
East & 0.274 & 0.77 & 0.123 & 0.22 & 89 \\
West & 0.274 & 0.80 & 0.119 & 0.20 & 90 \\
\hline Toluene \\
West & 0.316 & 0.77 & 0.603 & 0.22 & 65 \\
\hline
\end{tabular}

Assuming that high $(>2 \mathrm{ppb}) \mathrm{NO}_{x}$ is a signature of freshly contaminated air, we estimated the bulk contribution of motor vehicle exhausts, $\chi(T)$, to the near-surface abundance of toluene and benzene along the Trans-Siberian Railway from a simple relation:

$\chi(T) \frac{T_{\text {low }} \cdot t_{\text {low }}}{T_{\text {low }} \cdot t_{\text {low }}+T_{\text {high }} t_{\text {high }}} \cdot 100 \%$,

where $t_{\text {low }}$ and $t_{\text {high }}$ are the fractions of measurement time within air masses having low $(<3 \mathrm{ppb})$ and high $(\geq 3 \mathrm{ppb})$ $\mathrm{T} / \mathrm{B}$ ratios and $\mathrm{NO}_{x}>2 \mathrm{ppb}\left(t_{\text {low }}+t_{\text {high }}=1\right)$, and $T_{\text {low }}$ and $T_{\text {high }}$ are average toluene concentrations in the low- and high$\mathrm{T} / \mathrm{B}$ air masses, respectively (see Table 4).

One can see from Table 4 that motor vehicle exhausts were responsible for $\sim 90 \%$ of benzene levels and $\sim 65 \%$ of toluene levels during the campaign, that is, toluene emission from motor vehicle exhausts is $25 \%$ lower than the ben- 
zene one. It is comparable with the relative source contributions for benzene, and toluene presented in Karl et al. (2009). Thus, the motor vehicle exhausts were the most significant anthropogenic source of air pollution by toluene, and benzene in all the areas adjacent to the TROICA-12 route (densely populated areas along the Trans-Siberian Railway).

Benzene levels from the TROICA-12 campaign are broadly comparable in magnitude with other published data on their abundance in the summer urban and rural continental surface air (Elansky et al., 2000; Barletta et al., 2005; Na et al., 2005; Parra et al., 2006; Hoque et al., 2008; Tiwary et al., 2010; Seco et al., 2013; Wagner and Kuttler, 2014). However, toluene levels tended to be lower than those reported in earlier publications. This is possibly due to the more significant contribution of evaporative and industrial emissions in toluene levels (Karl et al., 2009) than that of mobile transport exhausts (which are about $65 \%$ for toluene from TROICA-12 measurements). It should be noted that no significant biomass burning along the Tran-Siberian railway was observed in the campaign, so this emission source is not expected to impact significantly on benzene and toluene levels.

\subsection{Diurnal variations in benzene and toluene}

To determine the contribution of diurnal variations in benzene and toluene to their surface levels and spatial variability, we analyzed their hourly mean concentrations measured in the campaign.

Observations in several locations (Filella et al., 2006; Zalel et al., 2008; Tiwary et al., 2010; Wagner and Kuttler, 2014) reported the highest levels of benzene and toluene being in the morning and evening hours due to the increase in the motor vehicle transport exhausts at this time. Contrary to these studies, no clear diurnal variation in benzene and toluene was observed in the TROICA-12 campaign (Fig. 4). We suppose that it is due to spatial smoothing of their diurnal variations in conditions of a lack of strong local pollution sources, which is clearly seen from median values. Somewhat higher levels in the morning (at 04:00-05:00 LT, local time) and in the evening (at 20:00 and 23:00 LT) are most probably due to accumulation of benzene and toluene in the stable atmospheric conditions in the vicinities of their regional sources transected on the TROICA route. Episodic crossing of anthropogenic pollution plumes during the campaign caused the midday peak (which falls occasionally at $\sim 12: 00 \mathrm{LT}$ ), seen in Fig. 4 from $P_{90}$ profile.

Thus, diurnal variations in the planetary boundary layer mixing regime did not contribute significantly to the spatial variability in benzene and toluene along the Trans-Siberian Railway in the TROICA-12 campaign. This allows us to neglect them further in summarizing the data at different spatial scales (for example, by different Russian regions and cities).

\subsection{Benzene and toluene levels in urban and rural surface air}

We found that the surface concentrations of VOCs, $\mathrm{NO}_{x}$, $\mathrm{CO}$, and $\mathrm{SO}_{2}$ were, in general, notably higher in urban areas (as would be expected), as most of regional pollution sources are located in cities and their suburbs (Table 5). It was found, however, that the highest $\left(>P_{95}\right)$ concentrations of all the pollutants including benzene and toluene were measured outside the cities, so they can not be attributed to the direct impact of urban pollution sources. A closer examination showed that these events were most probably connected to specific transport conditions favorable for maintaining anthropogenic plumes from large upwind sources, i.e., towns and industrial manufacturers away from the railway, as highly coherent structures at timescales of the order of a few hours to $10 \mathrm{~h}$. The most prominent events of crossing industrial plumes took place in ER (up to $37 \mathrm{ppb}$ for benzene), SCS (up to $39 \mathrm{ppb}$ for benzene), SES (up to $46 \mathrm{ppb}$ for toluene) and FE (up to $41 \mathrm{ppb}$ for benzene).

One can see from Table 6 that there was a statistically significant moderate correlation $(R \approx 0.5)$ between benzene and toluene both in urban and rural areas. In urban environments, there was a stronger correlation between benzene and toluene and $\mathrm{CO}(R \approx 0.6)$, as well as between $\mathrm{NO}_{x}$ and $\mathrm{CO}$, which can point to motor vehicle transport as their main common emission source. In urban areas, benzene also had a significant moderate correlation with NMHC, which can indicate partial input from the industrial exhausts: hydrocarbon processing, refining industry, fuel transportation and storage, tank and pipeline leaks, etc.

In rural areas (identified as those outside the towns with additional constraint $\mathrm{NO}_{x}<0.2 \mathrm{ppb}$; see Sect. 3.1), correlation between all the species studied was very poor, except for that between benzene and toluene. Evidently, the diversity of transport pathways, photochemical aging, and irreversible mixing of air masses subjected to different rates of anthropogenic contamination precludes direct quantification of primary pollutant sources for the substantial part of the TROICA route away from areas of their immediate impact.

To study atmospheric pollution in Russian cities along the Trans-Siberian Railway, 29 cities were selected, for which the total amount of measurement time was at least $25 \%$ of the whole residence time in the city. The highest concentrations of benzene and toluene (up to $5 \mathrm{ppb}$ ) were observed in industrial towns: Perm and Kirov (European Russia); Kungur and Yekaterinburg (south Ural Mountains region); Tyumen (west Siberia); Angarsk, Irkutsk, and Ulan-Ude (east Siberia); and Birobidzhan and Khabarovsk (Far East region; Fig. 5). In these cities the highest levels of $\mathrm{NMHC} \mathrm{NO}_{x}$, and $\mathrm{CO}$ were also measured (Fig. 6). Evidently, high $\mathrm{CO}$ abundances found in some of these towns point to the significant contribution to the overall pollution rates from refineries and central heating and power plans, which was also confirmed by the high T / B ratios ( $>3-4$ based on $P_{90}$ re- 
Table 5. Surface levels of the studied impurities in urban and rural areas along the Trans-Siberian Railway. All impurities are in ppb except for NMHC and CO (ppm).

\begin{tabular}{lrrrrrrrr}
\hline Compound & $N$ & Mean & \multicolumn{7}{c}{$\sigma$} & Min & Max & $P_{10}$ & $P_{50}$ & $P_{90}$ \\
\hline \multicolumn{7}{c}{ Urban } \\
\hline $\mathrm{N}_{6} \mathrm{H}_{6}$ & 10492 & 0.37 & 0.33 & 0.01 & 2.94 & 0.12 & 0.26 & 0.67 \\
$\mathrm{C}_{7} \mathrm{H}_{8}$ & 10492 & 0.70 & 1.34 & 0.04 & 22.56 & 0.17 & 0.39 & 1.30 \\
$\mathrm{NMHC}$ & 7571 & 0.26 & 0.24 & 0.09 & 2.65 & 0.14 & 0.20 & 0.39 \\
$\mathrm{NO}_{x}$ & 11052 & 11.95 & 16.14 & 0.75 & 205.64 & 2.78 & 7.57 & 23.82 \\
$\mathrm{CO}$ & 7239 & 0.27 & 0.08 & 0.14 & 0.68 & 0.20 & 0.25 & 0.36 \\
$\mathrm{SO}_{2}$ & 7518 & 1.38 & 1.16 & 0.04 & 10.74 & 0.35 & 1.16 & 2.48 \\
\hline & & & & & & & & \\
\hline $\mathrm{N}_{6} \mathrm{H}_{6}$ & 65703 & 0.21 & 0.43 & 0.01 & 36.51 & 0.07 & 0.15 & 0.37 \\
$\mathrm{C}_{7} \mathrm{H}_{8}$ & 65703 & 0.28 & 0.47 & 0.01 & 45.58 & 0.08 & 0.20 & 0.51 \\
$\mathrm{NMHC}$ & 51497 & 0.16 & 0.09 & 0.03 & 3.42 & 0.11 & 0.14 & 0.21 \\
$\mathrm{NO}_{x}$ & 79941 & 4.38 & 5.07 & 0.56 & 237.98 & 1.46 & 3.38 & 7.70 \\
$\mathrm{CO}^{5 O}$ & 50256 & 0.23 & 0.07 & 0.05 & 2.77 & 0.17 & 0.22 & 0.28 \\
$\mathrm{SO}_{2}$ & 53502 & 1.22 & 0.82 & 0.10 & 9.80 & 0.30 & 1.10 & 2.20 \\
\hline
\end{tabular}

Table 6. Pearson correlation matrix for urban and rural measurements along the Trans-Siberian Railway. $R \geq 0.5$ are shown in bold. Asterisks show statistically significant correlations for $P=0.05$. All impurities are in ppb except for NMHC and CO (ppm).

\begin{tabular}{|c|c|c|c|c|c|c|}
\hline & $\mathrm{N}_{6} \mathrm{H}_{6}$ & $\mathrm{~N}_{5} \mathrm{H}_{8}$ & $\mathrm{NO}_{x}$ & $\mathrm{CO}$ & $\mathrm{SO}_{2}$ & NMHC \\
\hline \multicolumn{7}{|c|}{ Urban } \\
\hline $\mathrm{N}_{6} \mathrm{H}_{6}$ & 1 & $0.53 *$ & $0.23^{*}$ & $0.57 *$ & $0.35^{*}$ & $0.47 *$ \\
\hline $\mathrm{C}_{7} \mathrm{H}_{8}$ & $0.53 *$ & 1 & $0.15^{*}$ & $0.49 *$ & $0.18^{*}$ & $0.21 *$ \\
\hline $\mathrm{NO}_{x}$ & $0.23 *$ & $0.15^{*}$ & 1 & $0.47 *$ & $0.25 *$ & $0.21 *$ \\
\hline $\mathrm{CO}$ & $0.57 *$ & $0.49 *$ & $0.47 *$ & 1 & $0.25^{*}$ & $0.21 *$ \\
\hline $\mathrm{SO}_{2}$ & $0.35^{*}$ & $0.18 *$ & $0.25^{*}$ & $0.25 *$ & 1 & 0.01 \\
\hline NMHC & $0.47 *$ & $0.21 *$ & $0.21 *$ & $0.21 *$ & 0.01 & 1 \\
\hline \multicolumn{7}{|c|}{ Rural } \\
\hline $\mathrm{N}_{6} \mathrm{H}_{6}$ & 1 & $0.52 *$ & $0.10^{*}$ & $0.11 *$ & $0.08 *$ & $0.21 *$ \\
\hline $\mathrm{C}_{7} \mathrm{H}_{8}$ & $0.52 *$ & 1 & $0.17 *$ & $0.14 *$ & $0.07 *$ & $0.17 *$ \\
\hline $\mathrm{NO}_{x}$ & $0.10 *$ & $0.17 *$ & 1 & $0.22 *$ & $0.16^{*}$ & $0.16^{*}$ \\
\hline $\mathrm{CO}$ & $0.11^{*}$ & $0.14 *$ & $0.22 *$ & 1 & $0.13 *$ & $0.18^{*}$ \\
\hline $\mathrm{SO}_{2}$ & $0.08 *$ & $0.07 *$ & $0.16^{*}$ & $0.13 *$ & 1 & $0.13 *$ \\
\hline NMHC & $0.21 *$ & $0.17 *$ & $0.16^{*}$ & $0.18^{*}$ & $0.13 *$ & 1 \\
\hline
\end{tabular}

gional values). The specific $\mathrm{T} / \mathrm{B}$ ratios also indicate that Khabarovsk, Birobidzhan, Skovorodino, Tulun, Tajshet, and Tyumen are mainly polluted by industrial emissions, whereas Vladimir, Kungur, Yurga, and Krasnoyarsk are mainly polluted by transport exhausts. In other cities, motor vehicle transport was found to be a main pollution source, even though the contribution from other sources (including industrial emissions, coal burning and gasoline evaporation) was also important, as seen from the significantly higher $P_{90}$ values comparing to the average one calculated for rural regions (see Fig. 5). Benzene and toluene surface levels in the medium-sized towns of Siberia (e.g., Achinsk, Taishet, Nizh- neudinsk) were close to an average rural concentration calculated for the campaign (less than $0.3 \mathrm{ppb}$ ).

Unfortunately, exact quantification of inputs from various types of sources into anthropogenic contamination of urban air was inhibited when using the TROICA data due to the very limited amount of observations collected within a particular town. Considering that transport emissions occur when the T / B is in the range of 1-3 (Mugica et al., 2003; Tiwari et al., 2010; Carballo-Pat et al., 2014; Shaw et al., 2015), and supposing well-mixed conditions such that each measured air parcel represents a uniform mixture of pollutants from various sources within a town, we found that motor vehicle transport accounts for approximately $75 \%$ of an- 

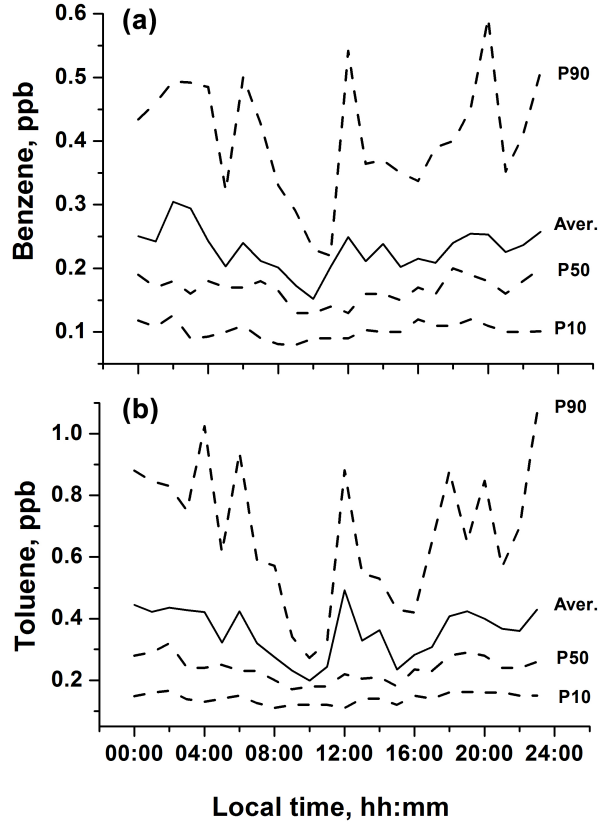

Figure 4. Diurnal profiles of the surface levels of benzene and toluene from TROICA-12 (hourly mean values): average (solid) and percentiles (dashed).

thropogenic emissions in the Russian cities along the TransSiberian Railway, with the remaining $25 \%$ being attributed to other sources (Fig. 7). These estimates correspond well to those derived in Sect. 3.1 based on the whole TROICA dataset. As seen from Fig. 8, the T/B ratio for vehicle urban exhausts in the Russian cities along the Trans-Siberian Railway is usually in the range of $2.3-2.8$.

\subsection{Contribution of VOCs to ozone formation potential over Russia}

Along the whole route of the TROICA campaign, the lower troposphere chemical regime was found to be essentially $\mathrm{NO}_{x}$ sensitive, both in rural and urban environments, with typical morning NMHC $/ \mathrm{NO}_{x}$ ratios being well above 20 . Hence, ozone production rates are expected to be controlled by regional $\mathrm{NO}_{x}$ emissions (Silman, 1999) and their complex interplay with both natural and anthropogenic sources of VOCs. As mentioned above, the meteorological conditions during most of the TROICA campaign were favorable for studying both chemical composition of fresh air masses contaminated by regional sources and ozone production from the emitted precursors due to high daytime surface air temperatures and solar radiation. To estimate the impact of the measured VOCs on regional ozone production, we employed widely used quantities: propylene-equivalent concentration (PE) and ozone-forming potential (OFP; Carter, 1994; So and Wang, 2004), which utilize the measured concentrations of VOCs along with their reactivity with the hydroxyl radical.

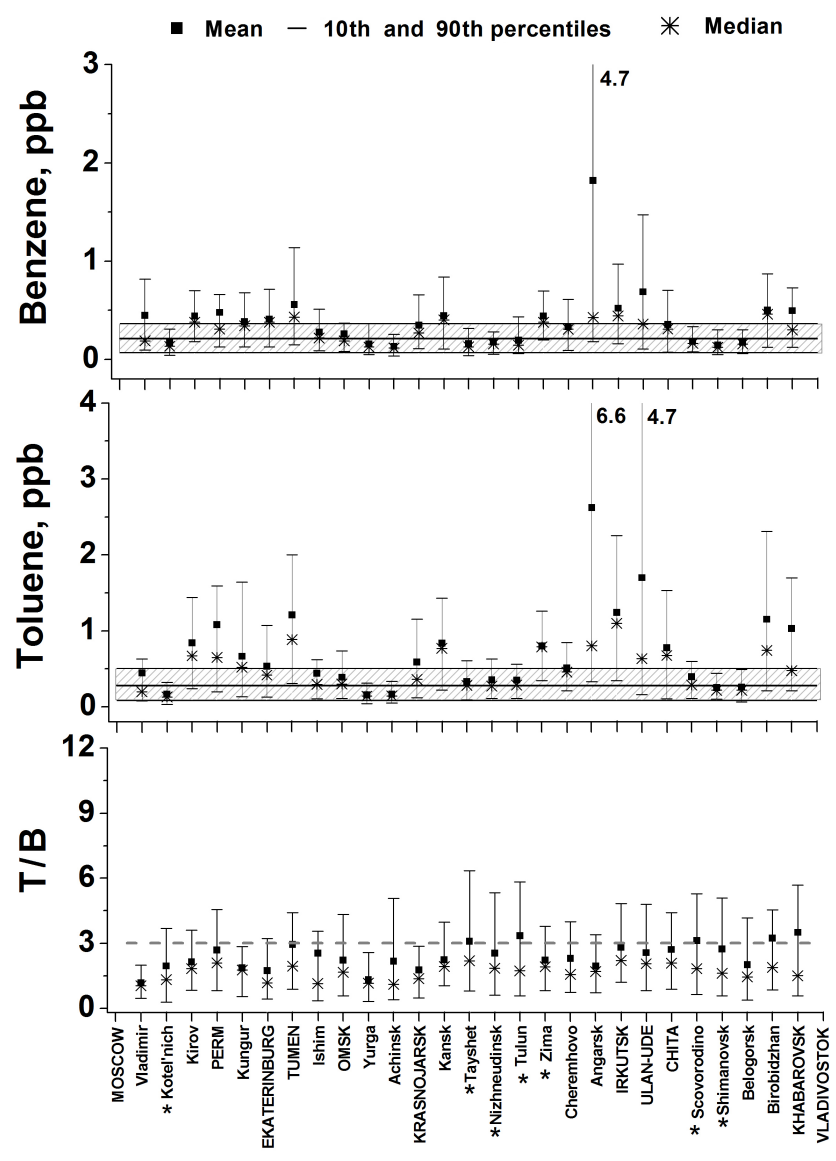

Figure 5. Benzene, toluene and $\mathrm{T} / \mathrm{B}$ in Russian cities along the Trans-Siberian Railway. The cities with a population from 250000 to 1 million or more are shown in capital letters, and the cities with a population from 50000 to 250000 in lowercase. Asterisks show cities with a population less than 50000 . The cities are shown in accordance with their location along the railway. The shaded area represents the mean, 10th and 90th percentiles calculated from the data measured in rural regions. The dotted line is a border between vehicle and industrial exhausts (Mugica et al., 2003; Tiwari et al., 2010; Carballo-Pat, 2014; Shaw et al., 2015).

These coefficients are defined as

$\mathrm{PE}_{\mathrm{VOC}}[\mathrm{ppbC}]=C_{\mathrm{VOC}} \times k_{\mathrm{OH}, \mathrm{VOC}} / k_{\mathrm{OH}, \text { propylene }}$,

$\mathrm{OFP}_{\mathrm{VOC}}\left[\mu \mathrm{g} \mathrm{m}^{-3}\right]=C_{\mathrm{VOC}} \times \mathrm{MIR}_{\mathrm{VOC}}$,

where is a VOC concentration in units of $\mathrm{ppbC}$ and $\mu \mathrm{g} \mathrm{m} \mathrm{m}^{-3}$ in Eqs. (1) and (2) is the rate constant for the reaction of VOC with the $\mathrm{OH}$ radical, the rate constant for the reaction between $\mathrm{OH}$ and propylene, and a maximum incremental reactivity. The last of these is a dimensionless quantity defined as grams of $\mathrm{O}_{3}$ produced per gram of the $\mathrm{VOC}$, which is equal to the maximum ozone concentration formed from chemical destruction of the given VOC.

We calculated PE and OFP values for benzene and toluene based on the daytime observations from 12:00 to 17:00 LT, the time for which the highest correlations between ozone 
Table 7. Averaged concentrations and photochemical properties of benzene, toluene and isoprene ( \pm standard deviation) from the TROICA12 campaign.

\begin{tabular}{lrrrrr}
\hline VOC & $10^{12} \times \mathrm{K}_{\mathrm{OH}}^{\mathrm{a}}$ & MIR $^{\mathrm{a}}$ & Concentration $(\mathrm{ppb})$ & $\mathrm{OFP}^{\mathrm{a}}\left(\mu \mathrm{g} \mathrm{m}^{-3}\right)$ & $\mathrm{PE}^{\mathrm{a}}\left(\mu \mathrm{g} \mathrm{m}^{-3}\right)$ \\
\hline Benzene & 1.23 & 0.42 & $0.20 \pm 0.33$ & $0.29 \pm 0.48$ & $0.06 \pm 0.09$ \\
Toluene & 5.96 & 2.70 & $0.28 \pm 0.51$ & $3.10 \pm 5.69$ & $0.44 \pm 0.81$ \\
Isoprene & 101.00 & 9.10 & $0.60 \pm 0.55$ & $16.65 \pm 15.19$ & $11.52 \pm 10.51$ \\
\hline
\end{tabular}

${ }^{a}$ Rate constants of VOCs with OH at $298 \mathrm{~K}\left(\mathrm{sm}^{3}\right.$ molecule ${ }^{-1} \mathrm{~s}^{-1}$; Atkinson, 1989; Atkinson and Arey, 2003). ${ }^{\mathrm{b}}$ Maximum incremental reactivity ( $\mathrm{g} \mathrm{O}_{3} / \mathrm{g}$ VOC; Carter, 1994).
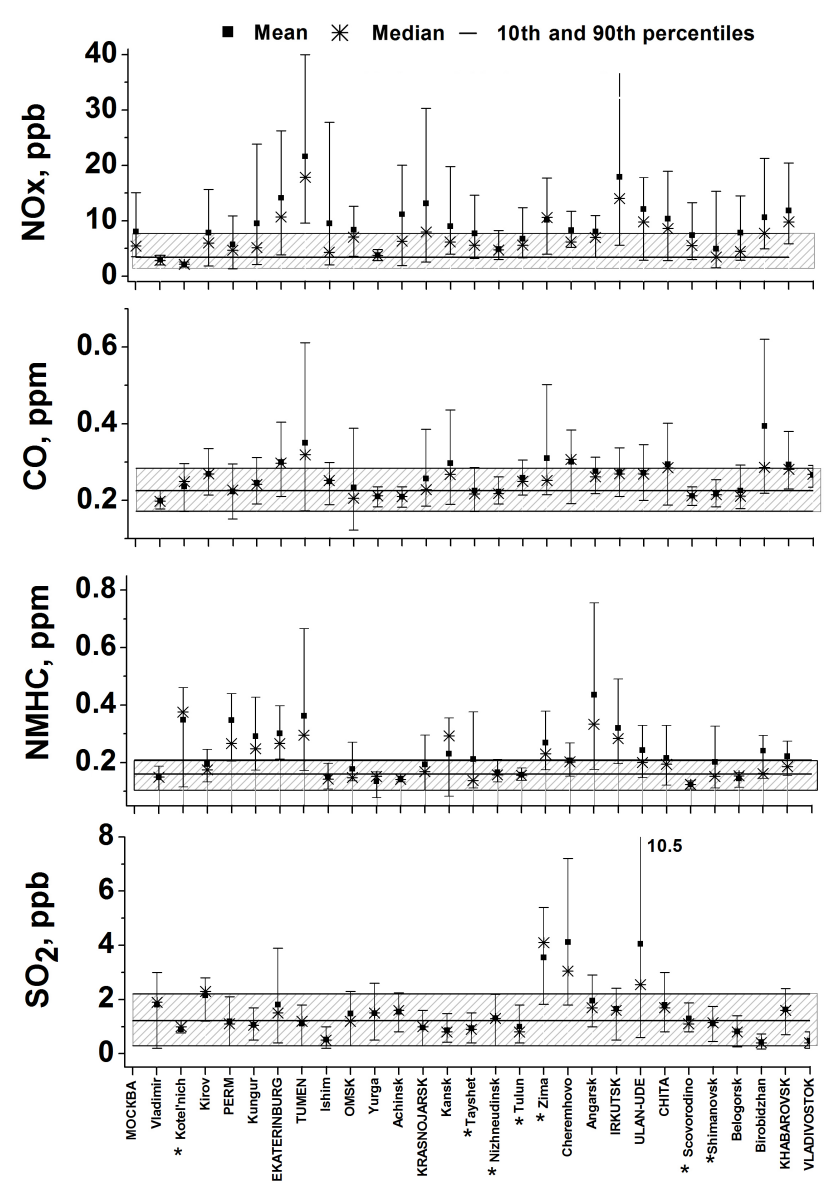

Figure 6. Inorganic impurities in Russian cities along the TransSiberian Railway. The cities with a population from 250000 to 1 million or more are shown in capital letters, and the cities with a population from 50000 to 250000 in lowercase. Asterisks show the cities with a population less than 50000 . The cities are shown in accordance with their location along the railway. The shaded area represents mean, 10th and 90th percentiles calculated from the data measured in rural regions.

and its precursor species were observed in TROICA as well. The calculated PE and OFP values were compared against those for isoprene, the latter of which is known as one the most important biogenic ozone precursors in rural as well as

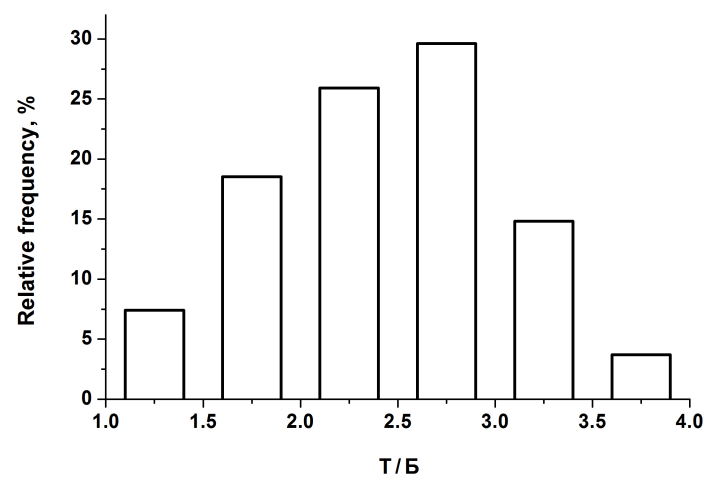

Figure 7. Frequency distribution of $\mathrm{T} / \mathrm{B}$ ratio for the Russian cities along the Trans-Siberian Railway.
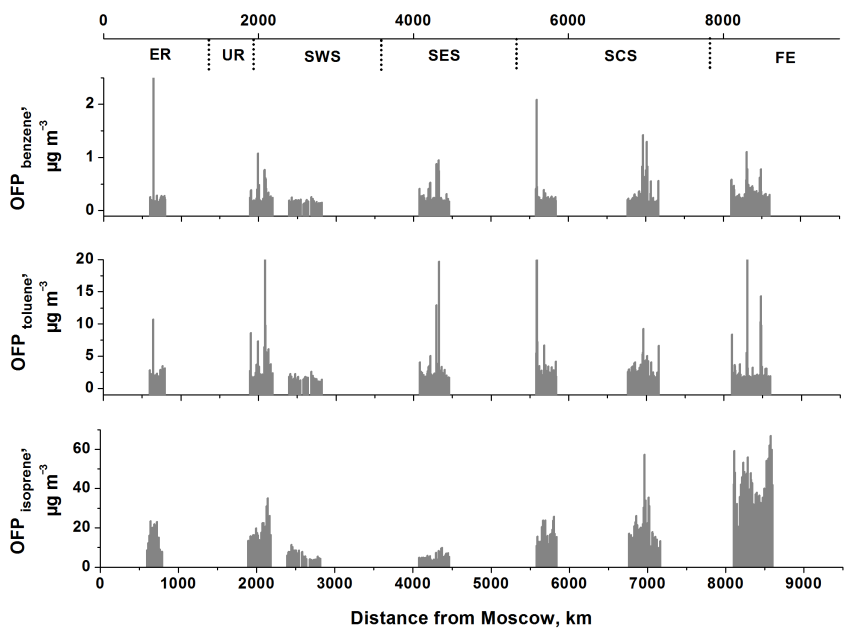

Figure 8. Ozone-forming potential (OFP) along the Trans-Siberian Railway from daytime measurements (12:00-17:00 LT).

urban settings (Chameides et al., 1988; Fuentes et al., 2000; Wagner and Kuttler, 2014).

As seen from Table 7, the average value of OFP of isoprene along the TROICA route is much higher compared to those for benzene and toluene, owing to relatively high nearsurface abundances of isoprene (approx. 3 times as much as that for the sum of benzene and toluene) and its exceptionally high reactivity with hydroxyl radical. According to Fig. 8, 
the process of oxidizing of isoprene proves to be the most important chemical source of ozone in all the regions along the TROICA route, as could be expected if one takes into account that the greater part of the railway crosses the areas with very weak to moderate anthropogenic load. The highest OFPs of isoprene seen in the figure in the Far East are due to its high biogenic emissions from broad-leaved forests as well as high surface air temperatures measured in this region in both the east and west segments of the route.

As seen from Fig. 8, the OFPs of benzene and toluene do not have significant large-scale spatial variations along the railway, contrary to that for isoprene. The highest OFPs shown as peaks in Fig. 8 are spatially connected to large towns and their vicinities along the railway where the relative input of benzene and toluene into ozone production reaches as high as $60-70 \%$ compared to that of isoprene. This supports our general notion of the reduced impact of regional anthropogenic sources on the regional ozone budget compared to long-range advection and regional biogenic VOC emissions (Shtabkin et al., 2016). Taking into account the important role of biogenic emissions of isoprene in the regional ozone photochemistry, we recommend that a detailed analyses of isoprene observations from the TROICA campaigns should be done in a separate publication.

\section{Summary}

Surface concentrations of two important anthropogenic VOCs, benzene and toluene, as well as inorganic compounds were measured simultaneously along the TransSiberian Railway on a mobile railway laboratory in the TROICA-12 campaign in summer 2008. It is demonstrated that the TROICA-12 measurements were carried out mostly in a moderately polluted $\left(2 \leq \mathrm{NO}_{x}<20 \mathrm{ppb}\right)$ environment ( $\sim 78 \%$ of measurements), with the remaining part of measurement time divided between weakly polluted $\left(\mathrm{NO}_{x} \leq 2 \mathrm{ppb}\right)$ and highly polluted $\left(\mathrm{NO}_{x}>20 \mathrm{ppb}\right)$ urban environments (20 and $2 \%$ of measurements, respectively). Maximum values of benzene and toluene during the campaign reached 36.5 and $45.6 \mathrm{ppb}$, respectively, which is significantly less than their short-term exposure limits ( 94 and $159 \mathrm{ppb}$ for benzene and toluene, respectively). However, the weather conditions during the major part of the TROICA campaign were favorable for accumulating anthropogenic pollutants in the lower atmosphere, the absence of clear diurnal variations in benzene and toluene along with their low abundances apart from the immediate vicinity of large towns and industrial manufactures points out to mostly unpolluted air conditions along the Trans-Siberian Railway during the campaign.

We estimated that motor vehicle exhaust accounts for $\sim 90 \%$ of benzene levels and $\sim 65 \%$ of toluene levels during the campaign, with the remaining 10 and $25 \%$, respectively, provided by other important regional anthropogenic sources: industrial enterprises, coal burning, evaporative emissions of VOCs etc.

The highest near-surface abundances of benzene and toluene, both in urban environment and on the regional scale, were observed in areas with the highest anthropogenic burden. They are industrial regions of the Southern Ural Mountain, European Russia, and the southern part of central Siberia, where spatially averaged benzene and toluene levels, representative of rural conditions, equal $\sim 0.3$ and $\sim 0.4 \mathrm{ppb}$, respectively. Vehicle emissions constitute the major part of total anthropogenic pollution in these regions, with a typical ratio of T / B of 2.2-2.3. Similarly, the highest concentrations of benzene (up to $5 \mathrm{ppb}$ ) and toluene (up to $7 \mathrm{ppb}$ ) along with high levels of $\mathrm{NMHC}, \mathrm{CO}$ and $\mathrm{NO}_{x}$ were observed in the following industrial towns: Perm and Kirov (European Russia); Kungur and Yekaterinburg (south Ural Mountains region); Tyumen (west Siberia); Angarsk, Irkutsk, and UlanUde (east Siberia); and Birobidzhan and Khabarovsk (Far East region).

Considering that transport emissions occur when the $\mathrm{T} / \mathrm{B}$ is in the range of 1-3 and supposing well-mixed conditions such that each measured air parcel represents a uniform mixture of pollutants from various sources within a town, we found that motor vehicle transport accounts for approximately $75 \%$ of anthropogenic emissions in the Russian cities along the Trans-Siberian Railway, with the remaining $25 \%$ attributed to industrial sources. T/B ratio for vehicle urban exhausts in the Russian cities along the Trans-Siberian Railway is usually in the range of 2.3-2.8.

The contribution of benzene and toluene to the local photochemical ozone production along the Trans-Siberian Railway is generally not significant compared to biogenic VOCs in rural environment and reaches as much as $16 \%$ of that of isoprene. However, in large towns the contribution of benzene and toluene to ozone formation reaches $60-75 \%$ compared to isoprene, supporting the important role of anthropogenic sources in local pollution.

Data availability. The data used in this study are available from the authors upon request (askorokhod@mail.ru; e_berezina_83@mail.ru).

Competing interests. The authors declare that they have no conflict of interest.

Acknowledgements. The authors thank Shumsky R. A. for active participation in designing the measurement set of the mobile laboratory and verifying its correct work and Lavrova O. V. for active participation in the campaign and careful diary observations. This study was supported by the Russian Science Foundation (grant no. 14-47-00049) and the Russian Foundation for Basic Research (grant no. 16-35-00158) and contributes to the Pan-Eurasian Experiment (PEEX) program research agenda. 
Edited by: V.-M. Kerminen

Reviewed by: two anonymous referees

\section{References}

Atkinson, R. and Arey, J. Atmospheric Degradation of Volatile Organic Compounds, Chem. Rev., 103, 4605-4638, 2003.

Baltaretu, C. O., Lichtman, E. I., Hadler, A. B., and Elrod, M. J.: Primary atmospheric oxidation mechanism for toluene, J. Phys. Chem. A, 113, 221-30, doi:10.1021/jp806841t, 2009.

Barletta, B., Meinardi, S., Rowland, F. S., Chan, C. Y., Wang, X. M., Zou, S. C., Chan, L. Y., and Blake, D. R.: Volatile organic compounds in 43 Chinese cities, Atmos. Environ., 39, 5979-5990, 2005.

Berezina, E. V., Elansky, N. F., Moiseenko, K. B., Safronov, A. S., Skorokhod, A. I., Lavrova, O. V., Belikov, R. A., and Shumsky, I. B.: Estimation of biogenic $\mathrm{CH}_{4}$ and $\mathrm{CO}_{2}$ emissions and dry deposition of $\mathrm{O} 3$ using 222Rn measurements in TROICA expeditions, Izvestiya, Atmos. Ocean. Phys., 50, 583-594, 2014.

Brocco, D., Fratarcangelli, R., Lepore, L., Petricca, M., and Ventrone, I.: Determination of aromatic hydrocarbons in urban air of Rome, Atmos. Environ., 31, 557-566, 1997.

Calvert, J. G., Atkinson, R., Becker, K. H., Kamens, R. M., Seinfeld, J. H., Wallington, T. J., and bYarwood, G. (Eds.): The mechanisms of atmospheric oxidation of aromatic hydrocarbons; Oxford University Press: Oxford, UK, 2002.

Carballo-Pat., C. G., Cerón-Bretón, J. G., Cerón-Bretón, R. M., Ramírez-Lara, E., Aguilar-Ucán, C. A., Montalvo-Romero, C., Guevara-Carrió, E., Córdova-Quiroz, A. V., Gamboa-Fernández, J. M., and Uc-Chi, M. P.: Latest trends in Energy. Environment and Development. Proceedings of the 7-th International Conference on Environmental and Geological Sciences and Engineering (EG'14), Salerno., Italy, 3-5 June, 132-140, 2014.

Carter, W. P. L.: Development of Ozone Reactivity Scales for Volatile Organic Compounds, J. Air Waste Manage. Assoc., 44, 881-899, 1994.

Chameides, W. L., Lindsay, R. W., Richardson, J., and Kiang, C. S.: The role of biogenic hydrocarbons in urban photochemical smog: Atlanta as a case study, Science, 241, 1473-1475, 1988.

Chameides, W. L., Fehsenfeld, F., Rodgers, M. O., Cardelino, C., Martinez, J., Parrish, D., Lonneman, W., Lawson, D. R., Rasmussen, R. A., Zimmerman, P., Greenberg, J., Middleton, P., and Wang, T.: Ozone precursor relationship in the ambient atmosphere, J. Geophys. Res.-Atmos., 97, 6037-6055, 1992.

Chaudhary, S. and Kumar, A.: Monitoring of benzene, toluene, ethylbenzene and xylene (BTEX) concentrations in ambient air in Firozabad, India, Int. Arch. Appl. Sci. Technol., 3, 92-96, 2012.

Civan, M. Y., Kuntasal, O. O., and Tuncel, G.: Source apportionment of ambient volatile organic compounds in Bursa, a heavily industrialized city in turkey, Environ. Forensics, 12, 357-370, 2011

Crutzen, P. J., Elansky, N. F., Hahn, M., Golitsyn, G. S., Brenninkmeijer, C. A. M., Scharffe, D., Belikov, I. B., Maiss, M., Bergamaschi, P., Rockmann, T., Grisenko, A. M., and Sevastyano, V. V.: Trace gas measurements between Moscow and
Vladivostok using the Trans-Siberian Railroad, J. Atm. Chem., 29, 179-194, 1998.

de Gouw, J. and Warneke, C.: Measurements of volatile organic compounds in the Earth's atmosphere using protontransferreaction mass spectrometry, Mass Spectrom. Rev., 26, 223-257, doi:10.1002/mas.20119, 2007.

Derwent, R. G., Davies, T. J., Delaney, M., Dollard, G. J., Field, R. A., Dumitrean, P., Nason, P. D., Jones, B. M. R., and Pepler, S. A.: Analysis and interpretation of the continuous hourly monitoring data for 26 C2-C6 hydrocarbons at 12 United Kingdom sites during 1996, Atmos. Environ. 34, 297-312, 2000.

Elansky, N. F., Golitsyn, G. S., Vlasenko, T. S., and Volokh, A. A.: Volatile organic compounds observed in the atmospheric surface layer along the Trans-Siberian Railroad, Dokl. Akad. Nauk, 373, 816-821, 2000.

Elansky, N. F., Golitsyn, G. S., Vlasenko, T. S., and Volokh, A. A.: Concentrations of Volatile Organic Compounds in Surface Air along the Trans-Siberian Railroad, Izvestiya, Atmos. Ocean. Phys., 37, S10-S23, 2001.

Elansky, N. F., Belikov, I. B., and Berezina, E. V.: Atmospheric composition observations over Northern Eurasia using the mobile laboratory: TROICA experiments, edited by: Elansky, N. F., Moscow, 73 pp., 2009.

Filella, I. and Peñuelas, J.: Daily, weekly, and seasonal time courses of VOC concentrations in a semi-urban area near Barcelona, Atmos. Environ., 40, 7752-7769, 2006.

Fortner, E. C., Zheng, J., Zhang, R., Berk Knighton, W., Volkamer, R. M., Sheehy, P., Molina, L., and André, M.: Measurements of Volatile Organic Compounds Using Proton Transfer Reaction - Mass Spectrometry during the MILAGRO 2006 Campaign, Atmos. Chem. Phys., 9, 467-481, doi:10.5194/acp-9-467-2009, 2009.

Fuentes, J. D., Lerdau, M., Atkinson, R., Baldocchi, D., Bottenheim, J. W., Ciccioli, P., Lamb, B., Geron, C., Gu, L., Guenther, A., Sharkey, T. D., and Stockwell, W.: Biogenic hydrocarbons in the atmospheric boundary layer: A review Bulletin of the American Meteorological Society, 1537-1575, 2000.

Geng, F., Tie, X., Guenther, A., Li, G., Cao, J., and Harley, P.: Effect of isoprene emissions from major forests on ozone formation in the city of Shanghai, China, Atmos. Chem. Phys., 11, 1044910459, doi:10.5194/acp-11-10449-2011, 2011.

Hoque, R. R., Khillare, P. S., Agarwal, T., Shridhar, V., and Balachandran, S.: Spatial and temporal variation of BTEX in the urban atmosphere of Delhi, India, Sci. Total Environ., 392, 30-40, 2008.

Karl, T., Apel, E., Hodzic, A., Riemer, D. D., Blake, D. R., and Wiedinmyer, C.: Emissions of volatile organic compounds inferred from airborne flux measurements over a megacity, Atmos. Chem. Phys., 9, 271-285, doi:10.5194/acp-9-271-2009, 2009.

Keymeulen, R., Gögényi, M., Héberger, K., Priksane, A., and Lagenhove. H. V.: Benzene, toluene, ethylbenzene and xylenes in ambient air and Pinussylvestris L. needles: a comparative study between Belgium, Hungary and Latvia, Atmos. Environ., 35, 6327-6335, 2001.

Lippmann, M.: Environmental Toxicants: Human Exposures and Their Health Effects, Wiley, 2009.

Miller, L., Xu, X. H., Wheeler, A., Atari, D. O., GrgicakMannion, A., and Luginaah, I.: Spatial Variability and Application 
of Ratios between BTEX in Two Canadian Cities, The Scientific World Journal, 11, 2536-2549, 2011.

Mugica, V., Ruiz, M. E., Watson, J., and Chow, J.: Volatile Aromatic Compounds in Mexico City atmosphere: Levels and Source apportionment, Atmosfera, 16, 15-27, 2003.

$\mathrm{Na}, \mathrm{K}$., Moon, K., and Kim, Y. P.: Source contribution to aromatic concentration and ozone formation potential in the atmosphere of Seoul, Atmos. Environ., 39, 5517-5524, 2005.

North, G. R., Pyle, J. and Zhang, F. (Eds.): Encyclopedia of Atmospheric Sciences, Second Edition, 90-109, 2015.

Panin L. V., Elansky N. F., Belikov I. B., Granberg I. G., Andronova A. V., Obvintsev Yu. I., Bogdanov V. M., Grisenko A. M., and Mozgrin V. S: Estimation of Reliability of the Data on Pollutant Content Measured in the Atmospheric Surface Layer in the TROICA Experiments//Izvestiya, Atmos. Ocean. Phys., 37, 8191, 2001.

Parra, M. A., González, L., Elustondo, D., Garrigó, J., Bermejo, R., and Santamaría, J. M.: Spatial and temporal trends of volatile organic compounds (VOC) in a rural area of Northern Spain, Sci. Total Environ., 370, 157-67, 2006.

Seco, R., Peñuelas, J., Filella, I., Llusia, J., Schallhart, S., Metzger, A., Müller, M., and Hansel, A.: Volatile organic compounds in the western Mediterranean basin: urban and rural winter measurements during the DAURE campaign, Atmos. Chem. Phys., 13, 4291-4306, doi:10.5194/acp-13-4291-2013, 2013.

Shaw, M. D., Lee, J. D., Davison, B., Vaughan, A., Purvis, R. M., Harvey, A., Lewis, A. C., and Hewitt, C. N.: Airborne determination of the temporo-spatial distribution of benzene, toluene, nitrogen oxides and ozone in the boundary layer across Greater London, UK, Atmos. Chem. Phys., 15, 5083-5097, doi:10.5194/acp-15-5083-2015, 2015.

Shtabkin, Y. A., Moiseenko, K. B., Skorokhod, A. I., Vasileva, A. V., and Heimann, M.: Sources of and variations in tropospheric CO in Central Siberia: Numerical experiments and observations at the Zotino Tall Tower Observatory, Izv. Atmos. Ocean. Phys., 52, 45-56, doi:10.1134/S0001433816010096, 2016.

Sillman, S.: The relation between ozone, $\mathrm{NO}_{x}$ and hydrocarbons in urban and polluted rural environments, Atmos. Environ., 33, 1821-1845, doi:10.1016/S1352-2310(98)00345-8, 1999.

Stein, A. F., Draxler, R. R, Rolph, G. D., Stunder, B. J. B., Cohen, M. D., and Ngan, F.: NOAA's HYSPLIT atmospheric transport and dispersion modeling system, B. Am. Meteorol. Soc., 96, 2059-2077, doi:10.1175/BAMS-D-14-00110.1, 2015.

So, K. L. and Wang T.: C3-C12 non-methane hydrocarbons in subtropical Hong Kong: spatial-temporal variations, source-receptor relationships and photochemical reactivity, Sci. Total Environ., 328, 161-174, 2004.
Tiwari, V., Hanai, Y., and Masunaga, S.: Ambient levels of volatile organic compounds in the vicinity of petrochemical industrial area of Yokohama, Japan, Air Qual. Atmos. Health, 3, 65-75, 2010.

Vasileva, A. V., Moiseenko, K. B., Mayer, J.-C., Jurgens, N., Panov, A., Heimann, M., and Andreae, M. O: Assessment of the regional atmospheric impact of wildfire emissions based on $\mathrm{CO}$ observations at the ZOTTO tall tower station in central Siberia, J. Geophys. Res., 116, D07301, doi:10.1029/2010JD014571, 2011.

Velasco, E., Lamb, B., Westberg, H., Allwine, E., Sosa, G., ArriagaColina, J. L., Jobson, B. T., Alexander, M. L., Prazeller, P., Knighton, W. B., Rogers, T. M., Grutter, M., Herndon, S. C., Kolb, C. E., Zavala, M., de Foy, B., Volkamer, R., Molina, L. T., and Molina, M. J.: Distribution, magnitudes, reactivities, ratios and diurnal patterns of volatile organic compounds in the Valley of Mexico during the MCMA 2002 \& 2003 field campaigns, Atmos. Chem. Phys., 7, 329-353, doi:10.5194/acp-7-329-2007, 2007.

Wagner, P. and Kuttler, W.: Biogenic and anthropogenic isoprene in the near-surface urban atmosphere-A case study in Essen, Germany, Sci. Total Environ., 475, 104-115, doi:10.1016/j.scitotenv.2013.12.026, 2014.

Warneke, C., van der Veen, C., Luxembourg, S., de Gouw, J. A., and Kok, A.: Measurements of benzene and toluene in ambient air using proton-transfer-reaction mass spectrometry: Calibration humidity dependence and field intercomparison, Int. J. Mass Spectrom., 207, 167-182, 2001.

Warneke, C., de Gouw, J. A., Kuster, W. C., Goldan, P. D., and Fall, R.: Validation of atmospheric VOC measurements by protontransfer-reaction mass spectrometry using a gaschromatographicpreseparation method, Environ. Sci. Technol., 37, 2494-2501, 2003.

Wayne, R. P. (Ed.): Chemistry of atmospheres; Oxford University Press, Oxford, UK, 2000.

White, M. L., Russo, R. S., Zhou, Y., Ambrose, J. L., Haase, K., Frinak, E. K., Varner, R. K., Wingenter, O. W., Mao, H., Talbot, R., and Sive, B. C.: Are biogenic emissions a significant source of summertime atmospheric toluene in the rural Northeastern United States?, Atmos. Chem. Phys., 9, 81-92, doi:10.5194/acp9-81-2009, 2009.

Zalel, A., Yuval, Y., Broday, D. M.: Revealing source signatures in ambient BTEX concentrations, Environ. Pollut., 156, 553-562, 2008. 